\title{
Corporate Finance and Firm Value in The Indonesian Manufacturing Companies
}

\author{
Eka Handriani", Robiyanto Robiyanto** \\ *Department of Management, Faculty of Economics and Business, Universitas Darul Ulum Islamic Centre Sudirman GUPPI, \\ Central Java, Indonesia \\ **Department of Management, Faculty of Economics and Business, Satya Wacana Christian University, \\ Salatiga, Central Java, Indonesia
}

\begin{tabular}{l} 
A R T I C L E I N F O \\
\hline Keywords: \\
Dividend policy, \\
Investment decision, \\
Funding Policy, \\
Firm Value, \\
Pecking Order Theory, \\
Agency Theory \\
\\
Kata kunci: \\
Kebijakan dividen, \\
Keputusan investasi, \\
Kebijakan pendanaan, \\
Nilai perusahaan Pecking Order Theory, \\
Agency Theory. \\
JEL Classification: \\
G32; G34
\end{tabular}

Corresponding author:

\section{A B S T R A C T}

This study examines the impact of dividend policy, investment decision, and funding policy on firm value in the Indonesian manufacturing companies. This study was conducted by using 178 manufacturing companies listed in the Indonesia Stock Exchange (IDX) during the period 2009 - 2016. Samples were taken by using a purposive sampling method. This study aims to examine the firm value's main determinants of the manufacturing companies in Indonesia based on basic theory of capital structure through building theoretical model. Partial Least Square through path analysis was used to analyze the data. The findings shows that dividend policy, investment decision, and funding policy have a positive impact on the Indonesian manufacturing companies' firm value. This study supports the theory of pecking order and agency theory.

SARI PATI

Penelitian ini mengkaji dampak kebijakan dividen, keputusan investasi, dan kebijakan pendanaan terhadap nilai perusahaan manufaktur di Indonesia. Penelitian ini dilakukan dengan menggunakan 178 perusahaan manufaktur yang terdaftar di Bursa Efek Indonesia (BEI) selama periode 2009 - 2016 sebagai sampel. Metode pengambilan sampel yang dipergunakan adalah purposive sampling. Penelitian ini bertujuan untuk menguji determinan utama perusahaan dari perusahaan manufaktur di Indonesia berdasarkan teori dasar struktur modal melalui model teoritis bangunan. Partial Least Square dengan analisis jalur digunakan untuk menganalisa data. Temuan ini menunjukkan kebijakan dividen, keputusan investasi, dan kebijakan pendanaan berdampak positif terhadap nilai perusahaan manufaktur Indonesia. Hasil penelitian ini mendukung teori pecking order dan agency theory.

(c) 2018 IRJBS, All rights reserved. 


\section{INTRODUCTION}

The Company aims to maximize shareholders' welfare through investment decisions and policies, Leverage and dividend decisions as reflected in stock prices in the stock market. This goal is often translated as an attempt to maximize corporate value (R. Ernayani, Oktiviana, \& Robiyanto, 2017; R. Ernayani, Robiyanto, \& Sudjinan, 2017; Qureshi \& Sharif, 2012). In reaching that goal, many shareholders are handing over the management of the company to the professionals responsible for managing the company, called the manager. Managers who are appointed by shareholders are expected to act on behalf of the shareholder, maximizing the value of the company so that the shareholder's welfare will be achieved (Purnamawati, Yuniarta, \& Astria, 2017).

The purpose of the company can be achieved through the implementation of the financial management functions carefully and appropriately, since any financial decision taken will affect other financial decisions that impact the value of the company. An optimal combination of the three financial decisions of investment decisions, funding, and dividend policy, will maximize the value of the firm, so the decision of the decision is mutually related to each other (R. Ernayani et al., 2017; R. Ernayani \& Robiyanto, 2016; Qureshi \& Sharif, 2012).

So it is not surprising that dividend policy has become an interesting topic to study. Various studies have reviewed the dividend policy, among others are Al-Malkawi, Rafferty, and Pillai (2010); Al Shabibi and Ramesh (2011); (Gusni, 2017); Handriani (2017); Handriani and Irianti (2015); John and Muthusamy (2010); Tyastari, Rosidi, and Saraswati (2017). Dividends are of concern to investors as they relate to investment returns. Setting the right dividend policy is an important task for managers because it has a great touch on the company's stock price and can also affect asset prices, capital structure, mergers and acquisitions, and capital budgeting (Robiyanto, 2015; Robiyanto
\& Puryandani, 2015; Suprianto \& Setiawan, 2017; Tyastari et al., 2017). In addition to dividend policy, investment decision is one of the determinants of corporate value (Wijaya, 2017).

According to Al-Tamimi (2009), investment decisions are defined as a combination of assets in place and future investment options with a positive net present value. In some studies that have been done for example Suteja and Mayasari (2017), IOS (investment opportunity set) used as a proxy for investment decisions, because investment decisions cannot be directly observed. Because IOS is a latent variable that can not be measured directly, it needs to be established or confirmed by various measurable variables (Pagalung, 2002). Baptista-Rui (2010) stated that some companies have started investing since the company is newly established and have chosen to diversify them (Dessyana \& Riyanti, 2017). While most research on corporate investments focuses on large enterprise diversification strategies and performance.

In this regard, corporate managers will always be in a position to know more about the value of assets and opportunities than investors. They know whether a project has a positive or negative NPV, and how to fund it. This certainly depends on the company's capital structure. Determining a capital structure policy should involve a tradeoff between risk and return. The addition of debt increases the total volatility of the cash flows or business risks of the firm, but also increases the expected ultimate returns. The higher risk of debt expansion tends to lower the stock price, but the expected increase in returns due to optimal debt use increases the stock price.

The optimal capital structure is a capital structure that balances risk and return so as to maximize stock prices. The main reason for using debt in financing corporate activities is that interest costs can be deducted in tax calculations, thereby lowering the true cost of debt. However, if a 
substantial proportion of the company's revenue has been spared from taxes due to accelerated depreciation or compensation of losses, then the progressive tax rate will be low and the benefits of using debt are also low (Sahabuddin, 2017). Debt is an instrument that is very sensitive to changes in corporate value determined by the capital structure. Managers should consider the benefits and costs of the selected funding sources in making Leverage (Buchari, Achsani, Tambunan, \& Maulana, 2016). Each funding source has different financial consequences and features. The company owner prefers the firm to create debt at a certain level to raise the value of the company. In order for the owner's expectations to be achieved, the behavior of managers and commissioners must be controlled through the substitution of assets such as participation in the ownership of the company's shares.

Another important thing that is contained in the company is corporate governance (Mai, 2017). The structure of corporate governance is an organizational framework that governs the principles of corporate governance to be operational and controlled. The structure of corporate governance must be designed to support the running of the organization's activities in a responsible and controlled manner. The most important thing in the structure of corporate governance is the problem of control, so there needs to be a strict separation between the "decision making" and the "decision-making". Theoretically, good corporate governance practices can increase the value of a company by improving its financial performance and reducing the risks that a board may have with a favorable decision of its own (Hermiyetti \& Malik, 2013). In general corporate governance arises as an attempt to control self-serving management behavior by creating mechanisms and controls to enable a balanced profit and benefit sharing system for stakeholders so as to create efficiency and increase investor confidence. Institutional investors in ownership of shares have a structure marked by institutional ownership of shares. The role of the Institutional Ownership in the company will determine the policies or strategies that will be taken both short and long term to better monitoring the process of corporate governance.

This study aims to: firstly, analyze and evaluate the main determinants of the value of manufacturing firms in Indonesia based on the basic theory of capital structure through building theoretical models (conventional, structural, and dynamic) proposed; second, analyze dividend policy, investment decision, and capital structure based on the agency theory perspective, and test whether the determination of optimal funding sources for manufacturing companies in Indonesia.

\section{Literature Review}

Factors affecting firm value have been subject to debate in both theory and empirical research. The debate has focused on whether there is an optimal capital structure for a company or whether the level of debt use affects the firm's value. Zheng (2017) argues that the capital structure decision of an enterprise should be examined in terms of its impact on firm value. Zheng (2017) further states that if the decision of capital structure can affect the value of the firm, then the company must have a capital structure that is able to maximize their value. The purpose of a company should therefore focus on maximizing value through capital structure decisions (Murhadi, 2011; Nhung, Lien, \& Hang, 2017).

The selection of financial structures is a matter of the composition of funding to be used by the company, which means determining how much debt (leverage) will be used by the company to fund its assets. The funding structure is a permanent funding consisting of long-term debt, preferred stock, and shareholder capital. If all funds to finance the company's assets come from the owners in the form of ordinary shares, the company is not bound by a fixed obligation to pay interest on debts earned in the framework of the 
company's funding. Interest is a fixed financial cost to be paid and added to the fixed cost of the operation regardless of the profit rate of the company. So companies that use debt will be more risky than a company without debt, because in addition to having business risks, companies that use debt also have financial risks. Relevant theory to describe the condition is Pecking Order Theory which states that companies prefer internal funding rather than external funding, secure debt than risky debt and the last is ordinary shares (Nuswandari, 2013).

\section{Pecking Order Theory}

Pecking order theory was first introduced by Donaldson (1961). This theory demonstrates a hierachy in the search for corporate funds whereby firms have a specific preference order of capital used to finance their business. Due to information asymmetry between the company and potential investors, the company will prefer retained earnings in advance to pay dividends and investment opportunities. If the company requires external funds, it will prefer to choose the debt before external equity (Skinner \& Soltes, 2009). Internal equity is derived from retained earnings and depreciation. Debt is obtained from a creditor loan, while external equity is obtained because the company issues new shares. In short this theory prefers internal financing (funding obtained from the results of the company's operations in the form of retained earnings). The company prefers to use funding sourced from the internal company, because internal funds make the company has no burden to pay the debt at the end of the period (Mai, 2010). A decrease in interest payments on debt will cause the company to have an internal source of funds for investment.

Pecking Order Theory proposed by Myers (1984) uses the rationale that there is no specific debt to equity ratio target where there is only a hierarchy of the most preferred sources of funding by the firm. The essence of this theory is the existence of two types of external financing capital and internal financing. This theory explains why profitable companies generally use a small amount of debt. This is not because companies have low debt ratio targets, but because they require little external financing. Companies that are less profitable will tend to use larger debt for two reasons, namely: (1) internal funds are insufficient; and (2) debt is the preferred external source. Thus, the pecking order theory makes the hierarchy of funding sources, namely from internal (retained earnings), and external (debt and stock). Myers (1984) states that the selection of external sources is due to an information asymmetry between management and shareholders. Information asymmetry occurs because management has more information than shareholders.

\section{Agency Theory}

Agency theory states the separation of ownership and control of the firm, so that the distribution of stock ownership in the company becomes an important matter (Siahaan, 2013). When the control of the company is no longer done by the owner but left to the other party to manage the company's resources, then the problem that arises is the potential conflict in the relationship between the owner (principals) and the agent (agent) is often called agency problems. The agency relationship is described as a relationship arising from the existence of a contract established between the principal using the agent to provide services for the principal's interest.

Jensen and Meckling (1976) identify potential conflicts of interest between different stakeholders within the company. The conflict is due to the different goals of each party based on their position and importance to the company. Such conflicts are known as agency problems that actually arise when the principal is having trouble ensuring that the agent is acting in the best interest of the principal. Efforts to overcome this agency problem will lead to cost consequences called agency costs that will be borne by both principals and agents. In the agency problem condition, debt 
is a very sensitive instrument to changes in firm value determined by capital structure (Modigliani \& Miller, 1958). Hence, managers should consider the benefits and costs of selected funding sources in making funding decisions.

Each funding source has different financial consequences and features. The owner of the company prefers the firm to create debt at a certain level to raise the value of the company (Ullah, Fida, \& Khan, 2012). In order for the owner's expectations to be achieved, the behavior of managers and commissioners must be controlled through the substitution of assets such as participation in the ownership of the company's shares (John \& Muthusamy, 2010). This shareholding will align management interests with the company owner (Jensen \& Meckling, 1976). Thus equity holders' shifting can create the wisdom of insiders in managing the company. The asymmetric concepts of information in the agency theory structure can reveal the behavioral relationships of managers, shareholders with capital structure (Huang, Jiang, Liu, \& Zhang, 2011). The presence of asymmetric information will limit access to external funding. This fact prompted the company to choose internal funding rather than external funding.

\section{Dividend Policy and Firm Value}

Dividend policy plays an important role in determining the value of the firm. Shareholders view dividends as a signal the firm's ability to increase revenue. For investors, dividends represent returns that can be compared with other investment opportunities (Robiyanto, Wahyudi, \& Pangestuti, 2017). This return is called the dividend yield, which is the ratio of dividend payout to the price per share. There are a number of opinions that mention that the value of a firm is not influenced by dividends. Among them was Modigliani and Miller (1958), they argue that with perfect market assumptions, rational behavior and perfect certainty, finding a relationship that corporate value and dividend policy are irrelevant.
In fact, there is informational asymmetry, in which the selling party has more information about the firm's condition than the potential investor.

The presence of such different information will encourage the role of dividends as a signal for outsiders. The study of Raz and Amir (2014) concluded that there was a disapparing dividend phenomenon which showed a decrease in the information content that existed in the dividend payout policy. This decline in information content is predicted to result from an increase in institutional ownership, where institutions have better information than individual shareholders. This has an impact on the time of dividend announcement, the information in dividend payout has been reflected from the stock price in the market. So the dividend payout policy becomes very expensive and contains less information.

Skinner and Soltes (2009) finds evidence that the information content in dividend payments diminishes when compared to the early 20th century. Skinner and Soltes (2009) argued that in the early 20 th century managers lacked the means to convey information that existed in companies other than through financial statements. In such an environment, the dividend policy can be a signal about the condition of the firm's prospects. But nowadays, where managers almost always communicate the existing information on the firm by using various media based on information technology, the information content in the dividend payout policy becomes reduced (Irandoost, Hassanzadeh, \& Salteh, 2013).

The pecking order theory explains why the majority of external financing comes from debt and why firms with excess profitability have less debt for financing sources. Dividends paid by companies are also a factor in determining debt policy. A stable dividend policy will cause the company to provide funds to pay the dividends. The funds companies use to pay dividends usually come from retained earnings. Conversely, if the 
company has large debts, companies tend to reduce the amount of dividends distributed to shareholders because most of the profits will be used to pay interest and installments (Nur, 2014). The dividend payout mechanism can be used to replace the role of debt in the oversight of agency issues, but the relationship does not work effectively, so the dividend policy has no effect on debt policy.

This study was conducted on manufacturing companies listed on the Indonesia Stock Exchange (IDX), which is included in the emerging markets group with a weak protection against the rights of investors. Developing countries such as Indonesia where corporate governance structures and mechanisms are still very weak, dividend payouts are desired by shareholders (Taungke \& Supramono, 2015). The bigger firm value will make better dividend policy. Thus, based on the literature review described above, then hypothesis 1 in this study is firm value has a positive effect on dividend policy.

\section{Investment Decision and Firm Value}

Investment decisions are important factors in the firm's financial function. Tyastari et al. (2017) states that corporate value is solely determined by investment decisions. The opinion can be interpreted that the investment decision is important, because to achieve the firm's goal is to maximize shareholder wealth will only be generated through corporate investment activities (Hermuningsih, 2013). The purpose of the investment decision is to obtain a high level of profit with a certain level of risk. High gains accompanied by manageable risks, are expected to increase the value of the firm, which means increasing shareholder wealth (Handriani \& Irianti, 2015).

The funding decision is related to the company's decision to finance their investment and determine the composition of the funding source. From a managerial perspective, the core of the funding function is how the firm determines the optimal funding source to fund various investment alternatives, so as to maximize the value of the firm as reflected in its stock price. Investment is an action to invest the current funds into current assets and fixed assets in the hope of making a profit in the future (Kang, Lobo, \& Wolfe, 2015). Investment activities undertaken by the company are expected to provide optimal returns that are reused for investment activities (Handriani, 2016). According to Pecking Order Theory, companies tend to prioritize funding from internal sources to finance investment. If the need for funds is less then external funds are used in addition. Nuswandari (2013) stated that Pecking Order Theory as an alternative theory of corporate financing decisions, whereby firms will seek to fund their investments in order of risk.

According Subramaniam and Shaiban (2011), investment decisions are defined as a combination of assets in place and future investment options with a net present value positive. Thus, based on the literature review described above, it can hypothesis 2 in this study is investment decisions has a positive effect on firm value.

\section{Corporate Governance and Firm Value}

Corporate governance in general is a set of mutually balancing mechanisms between the actions and choices of managers with the interests of shareholders. This proxy research using the structure of corporate governance is institutional ownership. Studies on the effect of institutional ownership on firm value values have been widely practiced, as Boubakri, Cosset, and Some (2015) have argued that the level of institutional ownership in substantial proportions affects the firm's market value. The basis of this argument is that the greater the level of stock ownership by the institution, the more effective the control mechanism on the performance of management. This opinion is supported by empirical evidence discovered by Cornett, Marcus, Saunders, and Tehranian (2007), which found a significant positive-significant effect on institutional ownership of the firm's value. 
In the perspective of agency theory, agents who are risk adverse and self-interested will allocate resources from investments that do not increase the value of the firm to a more profitable investment alternative. Agency issues will indicate that the value of the company will increase if the company owner can control the behavior of management in order not to waste company's resources, either in the form of investment that is not feasible or in the form of shirking. Corporate governance is a system that regulates and controls companies that are expected to provide and increase the value of the company to shareholders. Thus, the implementation of good corporate governance is believed to increase the value of the company.

Ovtcharova (2003) found that firms with high institutional ownership will impact on high yield levels as well. This research is consistent with the concept that corporate governance is a control mechanism of managerial opportunistic behavior, where institutional ownership variables are one of the proxies. Thus, the hypothesis 3 that can be proposed is as follows: institutional ownership has a positive effect on firm value.

\section{Leverage and Firm Value}

There are two theoretical frameworks underlying the selection of funding sources namely Static Theory and Pecking Order Theory. Leverage with static theory are based on optimal capital structure, which balances the benefits of tax savings on debt use against bankruptcy costs (Myers, 1984). This Static Theory predicts a relationship of income variability or the volatility of cash flows with the use of debt. The purpose of this static theory is to balance its own capital with external capital. As long as the benefits of using the debt is still large, the debt will be increased, but if the sacrifice to use the debt is greater then the debt is no longer optimal to be added (Myers, 1984). Research finding consistent with static theory is shown by Panno (2003), in his empirical studies in the United Kingdom (UK) and Italy, where the UK whose well-developed financial markets tend to make adjustments to their long-term optimal leverage targets, while Italians whose financial markets are less efficient choosing to prioritize equity issuance rather than pursuing an optimal leverage ratio.

Modigliani and Miller (1958) with his Static Theory explains that firms with high profitability will use debt as a financing option in order to benefit from tax-saving facilities. With the presence of asymmetric information, make a positive signal for a profitable company. Research in line with this has been done by Wahyudi (2005). Wahyudi (2005) explains the optimal balance between debt with own capital revealed on the theory of capital structure aims to provide a basis for thinking to know the optimal capital structure. A capital structure is said to be optimal if a given level of risk can provide maximum corporate value. While Humphrey-Jenner and Powell (2011) discloses that increasing debt can create an incentive for shareholders to substitute assets (to shift risk) or reduce investment (to under-invest) projects with positive NPV.

Pecking order behavior other than influenced by the existence of information asymmetry also tend to be encouraged by the existence of taxes and transaction costs. There are several reasons why the direct cost of retained earnings will be less than the issuance of new equity. In this case, by setting the amount of debt and investment constant, the increase in equity issuance will always lead to a larger dividend (Kato, Loewenstein, \& Tsay, 2012). Larger dividends will further increase the tax burden (Tyastari et al., 2017). Therefore it would be reasonable if the company attempted to press the issuance of new equity. In addition, according to Brigham and Houston (2012), the cost is generally smaller if the company issues debt rather than issuing new shares. Companies in issuing external securities will prefer debt over shares to reduce the various costs arising from the selection of debt and stocks.

In relation to the value of the company, pecking order theory has given the idea that the use of debt 
will provide benefits as well as costs and risks as stated by Brigham and Houston (2012) who argued that the use of interest-bearing debt has advantages and disadvantages for the company. So the optimal use of debt and considered against the specific characteristics of the company (asset, market share and profitability) will prevent the company from the risk of failing fulfillment of obligations so that companies avoid the decline in investor confidence that implies the decline in corporate value. This condition poses a potential conflict of interest between shareholders and creditors. Thus, based on the literature review described above, the hypothesis 4 that can be proposed is as follows: funding decision has a positive effect on firm value.

\section{Firm Size and Firm Value}

The size of the firm is thought to affect the value of the firm, where large firms tend to attract attention and become the public spotlight, thus firm size has a positive effect on firm value (R. Ernayani \& Robiyanto, 2016; Handriani \& Irianti, 2015). Firm size can be interpreted as a scale which can be classified large small companies in various ways, among others stated in total assets, stock market value, and others. In the study of Madanoglu, Lee, and Castrogiovanni (2011), explained that the total assets reflect how much wealth owned by a company and reflects the size of the company.

The size of the firm is seen from the total assets owned by the company that can be used for the company's operations. If the firm has a large asset, the management is more flexible in using the existing assets in the firm. When viewed from the side of management, ease of having in controlling the firm will increase the value of the company. The size of the firm describes the size of a company indicated by total assets and total sales (Handriani \& Irianti, 2015). Thus it can be concluded that the size of the firm can be seen from the size of capital used, total assets owned, or total sales obtained.

The size of the firm is considered capable of affecting the firm value because the larger the firm size, will be more easily also the firm obtain sources of funding both internal and external. Firm size also important in capital structure. Large companies basically have greater financial strength to support performance, but on the other hand, companies are faced with greater agency problems.

Company size can determine the level of ease of the company in obtaining funds from the capital market and determine the bargaining power (bargaining power) in financial contracts. Pecking order behavior of large companies against debt is very small, they take advantage of retained earnings to finance corporate activities. Small companies usually can choose funding from various forms of debt, including special offers that are more profitable. Large companies will more easily access funding through the capital market. This convenience is good information for investment decision making and can also reflect the value of the company in the future. Wahyudi (2005) states that the larger the size of the company will be the higher the value of the company. Thus, based on the literature review described above, then hypothesis 5 in this study is firm size has a positive effect on firm value.

\section{METHODS}

\section{Population, Sampling and Data}

Population in this study are manufacturing companies listed in the IDX during period 2009 - 2016. By using purposive sampling method with data availability criteria, there are 178 manufacturing companies selected as samples. Data used in this study obtained from the Indonesian Capital Market Directory published by the IDX

\section{Path Analysis}

This research uses path analysis to know and analyze the influence of exogenous variables on endogenous variables. Hair, Black, Babin, and Anderson (2009) states that there are four steps that must be taken to use this path analysis, namely: 1) 
developing a model, which must be done based on theory; 2) developing a path diagram to show causality; 3 ) the conversion of line diagrams into a series of structural equations and measurement model specifications; and 4) the selection of the input matrix and the estimation technique of the built model. In this study, it can be arranged 2 the regression equation as follows:

Dividen Policy (DPR):

$\mathrm{DPR}=\beta_{1}$ Tobinsq $+\mathrm{e}_{1}$

Firm Value (Tobinsq):

Tobinsq $=\beta_{2} \mathrm{IOS}+\beta_{3} \mathrm{IO}+\beta_{4} \mathrm{LEV}+\beta_{5} \mathrm{TS}+\mathrm{e}_{2} \ldots$ (2) Variables
Variable type of this study consist of exogenous variables: dividend policy, good corporate governance, leverage, firm size, IOS. Endogenous Variables: dividend policy and firm value. Table 1 . describe each variable.

\section{Results}

The goodness of fit results of path analysis shows the following information. See Table 2.

These results indicate that all goodness of fit index models built are fit. This can be seen from the value in the model result column, where the value corresponds to the desirable on the cut off value column. The significance level (probability)

Table 1. Operational Variable Definition

\begin{tabular}{|c|c|c|}
\hline Variables & Indicators & Measurement \\
\hline \multirow{2}{*}{$\begin{array}{l}\text { Firm Value } \\
\text { Is a measure of the amount } \\
\text { of total wealth (total assets) } \\
\text { owned by the company }\end{array}$} & \multirow[t]{2}{*}{ Tobins'q } & (Current Price $\mathrm{x}$ Total Share) + (Total Liabilities) \\
\hline & & $\begin{array}{l}\text { Total Assets } \\
\end{array}$ \\
\hline \multirow{3}{*}{$\begin{array}{l}\text { Dividend Policy } \\
\text { Is a size (proportion) of the } \\
\text { company's net profit shared } \\
\text { to the stockholder. }\end{array}$} & \multirow{3}{*}{$\begin{array}{l}\text { Dividend Pay Out } \\
\text { Ratio (DPR) }\end{array}$} & \multirow{2}{*}{$\mathrm{DPR}=\frac{\mathrm{DPS}}{\mathrm{EPS}}$} \\
\hline & & \\
\hline & & $\begin{array}{c}\text { DPR = Dividend Payout Ratio } \\
\text { DPS = Dividend Per Share } \\
\text { EPS = Earnings Per Share }\end{array}$ \\
\hline
\end{tabular}

Good Corporate Governance Institusional

A system established to

control and direct the

company's operations

\begin{tabular}{lll}
\hline $\begin{array}{l}\text { Funding Policy } \\
\text { Is a size } \\
\text { (proportion) of } \\
\text { use of total debt to finance } \\
\text { the whole } \\
\text { investment company. }\end{array}$ & $\begin{array}{l}\text { Leverage } \\
\text { (Lev) }\end{array}$ & Leverage $=\frac{\text { Total Debt }}{\text { Total Assets }}$ \\
\hline $\begin{array}{l}\text { Invesment } \\
\begin{array}{l}\text { A result of future investment } \\
\text { options to benefit from the } \\
\text { growth prospects of the } \\
\text { company. }\end{array}\end{array}$ & $\begin{array}{l}\text { Investment } \\
\text { (IOS) }\end{array}$ & \\
\hline $\begin{array}{l}\text { Firm Size } \\
\text { Is a measure of the amount } \\
\text { of total wealth (total assets) } \\
\text { owned by the company }\end{array}$ & & \\
\hline
\end{tabular}

Ownership

(IO)

Percentage of the number of shares owned by the institution from the total number of shares outstanding.

Source: Various previous studies. 
Table 2. Path Analysis's Goodness of fit

\begin{tabular}{lccc}
\hline \multicolumn{1}{c}{ Goodness of Fit Index } & Cut-off Value & Result & \multicolumn{2}{c}{ Model Evaluation } \\
\hline Chi - Square & 14.067 & 8.845 & Fit \\
Probability & $\geq .05$ & .487 & Fit \\
CFI & $\geq .90$ & .96 & Fit \\
CMIN/DF & $<3$ & 1.42 & Fit \\
NFI & $\geq .90$ & .92 & Fit \\
GFI & $\geq .90$ & .95 & Fit \\
AGFI & $\geq .90$ & .93 & Fit \\
RMSEA & $\leq .08$ & .02 & Fit \\
\hline
\end{tabular}

Source: Data processed by LISREL.

of .487 indicates that the null hypothesis states that there is no difference between the sample covariance matrix and the population covariance matrix which the estimation fails or rejects. Acceptance of the null hypothesis shows that this acceptable model can be reinforced with other goodness of fit indices such as CFI (.96), CMIN / DF (1.42), NFI (.92), GFI (.95), AGFI (.93), RMSEA (.02) provide strong confirmation for the acceptability of the model.

\section{Hypothesis Testing}

Based on the calculation through path analysis that includes DPR variables, Leverage, Investment Opportunity Set (IOS), Size and firm value (Tobinsq). The next stage is to test the hypothesis proposed, the hypothesis test results can be seen based on the magnitude of the critical ratio (cr), probability and standardized regression weight in Table 3 . The critical ratio value above 2.56 will produce significant estimation value at level $(\alpha)$ $1 \%$ while the critical value ratio greater than 1.96 indicates a significant estimation value at the $(\alpha)$ level of $5 \%$.

To facilitate in giving conclusion to result of this research hence presented summary test result for all hypothesis in Table 4.

\section{RESULTS AND DISCUSSION}

Investment decisions, in this study affect the firm valuein the perspective of agency theory. This research is in line with the research that has been done by Adam, Jappelli, Menichini, Padula, and Pagano (2002); Prasetyantoko (2006). How much the investment opportunity value of a project project that generates a positive NPV for the company will affect the manager's, investors 'and creditors' perspective on the firm value. For investors who plan to invest in a company,

Table 3. Test results of Dividend Policy, Investment Decision, Funding Policy, and the Firm Value of the Indonesian Manufacturing Companies

\begin{tabular}{ccccccc}
\hline & & Estimate & S.E. & C.R. & P \\
\hline DPR & $\longleftarrow$ & Tobinsq & .130 & .063 & 7.162 & .000 \\
Tobinsq & $\longleftarrow$ & IOS & .166 & .091 & 11.930 & .000 \\
Tobinsq & $\longleftarrow$ & IO & .027 & .072 & 8.513 & .004 \\
Tobinsq & $\longleftarrow$ & LEV & .047 & .040 & 13.672 & .002 \\
Tobinsq & $\longleftarrow$ & TS & .234 & .378 & 9.646 & .006 \\
\hline
\end{tabular}

Source: Data processed by LISREL. 
Table 4. Hypothesis Testing Result Summary

\begin{tabular}{lllll}
\hline & Hypothesis & $\begin{array}{l}\text { Predicted } \\
\text { Sign }\end{array}$ & $\begin{array}{l}\text { Standardized } \\
\text { Regression } \\
\text { Coefficient }\end{array}$ & Conclusion \\
\hline $\mathrm{H} 1: \quad \begin{array}{l}\text { firm value has a positive effect } \\
\text { on dividend policy }\end{array}$ & + & .230 & accepted \\
$\mathrm{H} 2: \quad \begin{array}{l}\text { Investment decision has a } \\
\text { positive effect on firm value }\end{array}$ & + & .352 & accepted \\
$\mathrm{H} 3: \quad \begin{array}{l}\text { Corporate governance has a } \\
\text { positive effect on firm value }\end{array}$ & + & .434 & accepted \\
$\mathrm{H} 4: \quad \begin{array}{l}\text { Funding policy has a positive } \\
\text { effect on firm value }\end{array}$ & + & .521 & accepted \\
H5 : & $\begin{array}{l}\text { Firm size has a positive effect on } \\
\text { firm value }\end{array}$ & + & .344 & accepted \\
\hline
\end{tabular}

the magnitude of growth opportunities will form a perspective on the magnitude of the return on investment.

Capital structure based on the perspective of Agency Theory, in this study have a positive effect on firm value. This research is in line with the research that has been done by Fauzi and Locke (2012); Ullah et al. (2012). A good capital structure is a capital structure that can provide a balance between the marginal use of debt and the marginal cost of debt use, but with the concept of agency costs, a good capital structure can be obtained by balancing the marginal cost of the debt agency with marginal cost of equity agency (Jensen \& Meckling, 1976). While, the positive influence of the institutional ownership structure on firm value suggests that the stronger the external control of the firm will encourage managers to increase the value of the firm and ultimately will result in a better dividend policy. High institutional ownership will also provide institutional power to oversee dividend policies made by corporate management.

Company size has a positive effect on firm value, in line with research done by R. Ernayani and Robiyanto (2016); Heaney et al. (2007); Humphrey-Jenner and Powell (2011); Symeou
(2011). In this study, firm size has a positive effect on firm value. This research is conducted in the emerging market country in accordance with the theory that underlies the relationship between the two variables of this research is agency theory. If the interests of managers and shareholders are completely aligned, then managers will distribute all free cash flow to shareholders. Managers tend to reduce the cash in their hands and be more careful in allocating the available funds, and more aimed at increasing the welfare of shareholders.

\section{MANAGERIAL IMPLICATIONS}

Based on the results of testing of all the hypotheses present in this study and discussion, as well as some conclusions which have been drawn then will be described how the implications of these findings. Overall, the concept of industry-based investment growth opportunities provides useful insights for assessing companies from the two models in this study. Firstly, the Dividend Policy (DPR) can affect the value of the company, this means that in the context of current macroeconomic uncertainty, investors are still expecting a dividend from their share ownership. Therefore the implications for managerial should try to routinely distribute dividends as a form of corporate commitment to its shareholders. Second, general macroeconomic conditions that can cause a business cycle in 
manufacturing industries where companies and managers operate. The lethargy in an industry is often related to the economic crisis that struck a particular industry this can be felt from the actions and reactions of competitors that cannot be predicted with certainty. Actions and reactions between companies in the industry can be minimized if the company's value in the eyes of investors can be achieved with the improvement of company performance. In this research, the second model shows that company value can be achieved with company's performance, that is investment, institutional ownership, leverage and sales increase.

Interaction of firm value with variable of company performance can give influence to investment desire of the company, this will influence change of profitability, leverage, and company's sales. The important implication is that the desire to invest in a manufacturing company is influenced by the use of debt used to finance it. The high funding requirement of this debt is for the company solely to finance the company's business strategy oriented to the increase in sales that is able to demonstrate market power, thus the debt-funded strategic actions allow the company to maintain its market share. Strategic action is always in the frame in the system of good corporate governance, in this study manifest in the mechanism of supervision of institutional ownership.

The design of an effective corporate oversight mechanism to get managers to act in the best interests of shareholders has become a concern in the best interests of shareholders has been a major concern in the corporate governance area. This issue is the main basis for research on agency theory, and attempts to design an appropriate framework for controlling it. Corporate governance is a controlling mechanism for managing and managing a company with a view to improving the company's prosperity and accountability, whose ultimate goal is to increase company value.

\section{CONCLUSION}

This study found that investment decision, corporate governance, funding policy and firm size have a positive influence on firm value. Furthermore, this research found that firm value has a positive effect on dividend policy. In this study, manufacturing companies in Indonesia are consistent with the agency theory. Companies in the emerging market tend to face informational asymmetry, where company managers have more information about the company's condition than the investors. So the company's value can be a benchmark of dividend policy.

This research contributes to a well-known corporate governance literature in the community. In general, Good Corporate Governance Structure and a good system to manage the company with the aim of increasing the value of the company is able to accommodate various stakeholders with stakeholders such as government and environment where the company stands. The test results of Institutional Ownership variables in this study have a positive effect on company value. In accordance with the Agency Theory that agency problem will occur if the proportion of Institutional Ownership of the company's shares is less than $100 \%$ so that managers tend to act for their own interests and not based on the maximization of corporate value in making investment decisions. Management does not bear the risk of making a decision, the risk is fully borne by the shareholders. 
REFERENCES

Adam, K., Jappelli, T., Menichini, A., Padula, M., \& Pagano, M. (2002). Analyse, Compare, and Apply Alternative Indicators and Monitoring Methodologies to Measure the Evolution of Capital Market. Centre for Studies in Economics and Finance (CSEF) Report.

Al-Malkawi, H. A. N., Rafferty, M., \& Pillai, R. (2010). Dividend policy: A review of theories and empirical evidence. International Bulletin of Business Administration, 9(1), 171-200.

Al-Tamimi, H. A. H. K. (2009). Financial Literacy and Investment Decisions of UAE Investors. The Journal of Risk Finance, 10(5), 500-516.

Al Shabibi, B. K., \& Ramesh, G. (2011). An empirical study on the determinants of dividend policy in the UK. International Research Journal of Finance and Economics, 80, 105-120.

Baptista-Rui, K. L. J. (2010). Diversification by Young. Small Firms, 1-37.

Boubakri, N., Cosset, J.-C., \& Some, H. Y. (2015). Introduction to Institutional Investors in Global Capital Markets. Institutional Investors in Global Capital Markets: Emerald Group Publishing Limited.

Brigham, E. F., \& Houston, J. F. (2012). Fundamentals of financial management: Cengage Learning.

Buchari, A., Achsani, N. A., Tambunan, M., \& Maulana, T. N. A. (2016). The Capital Structure of Venture Capital Firms in Indonesia. Jurnal Keuangan dan Perbankan, 20 (3).

Cornett, M. M., Marcus, A. J., Saunders, A., \& Tehranian, H. (2007). The impact of institutional ownership on corporate operating performance. Journal of Banking \& Finance, 31(6), 1771-1794. doi: 10.1016/j.jbankfin.2006.08.006

Dessyana, A., \& Riyanti, B. P. D. (2017). The Influence of Innovation and Entrepreneurial Self-Efficacy to Digital Startup Success. International Research Journal of Business Studies, 10(1). doi: https://doi.org/10.21632/irjbs.10.1.57-68

Donaldson, G. (1961). Corporate debt capacity: A study of corporate debt policy and the determination of corporate debt capacity. Boston, MA: Division of Research, Graduate School of Business Administration, Harvard University.

Ernayani, R., Oktiviana, S., \& Robiyanto, R. (2017). The Effect of Return on Investment, Cash Ratio, and Debt to Total Assets Towards Dividend Payout Ratio (A Study Towards Manufacturing Companies Listed in Indonesia Stock Exchange). Advanced Science Letters, 23(8), 7169-7199. doi: https://doi.org/10.1166/asl.2017.9328

Ernayani, R., \& Robiyanto, R. (2016). The effect of the cash flows, gross profit and company size on Indonesian stock returns (a study on the chemical and basic industry companies during the periods of 2009-2014). International Journal of Applied Business and Economic Research, 14(3).

Ernayani, R., Robiyanto, R., \& Sudjinan, S. (2017). Factors influencing profit distribution management of sharia commercial banks in Indonesia. Journal of Economics, Business \& Accountancy Ventura, 20(2). doi: 10.14414/jebav.v20i2.1055.

Fauzi, F., \& Locke, S. (2012). Board Structure, Ownership Structure and Firm Performance: a Study of New Zealand. Asian Academy of Management Journal of Accounting and Finance, 8(2), 43-67.

Gusni, G. (2017). The Determinants of Dividend Policy: A Study of Financial Industry in Indonesia. Jurnal Keuangan dan Perbankan, 21(4).

Hair, J. F., Black, W. C., Babin, B. J., \& Anderson, R. E. (2009). Multivariate Data Analysis (7 ed.): Pearson.

Handriani, E. (2016). Role of Investment Opportunity Based on Industrial Growth (Kibig) To Increase Company Value (Empirical Study on Manufacturing Company Go Public In Indonesian Capital Market). Dissertation, Universitas Diponegoro, Semarang, Indonesia.

Handriani, E. (2017). Memanfaatkan Peluang Investasi Berbasis Pertumbuhan Industri Untuk Meningkatkan Laba dan Nilai Perusahaan.

Handriani, E., \& Irianti, T. E. (2015). Investment Opportunity Set (IOS) Berbasis Pertumbuhan Perusahaan dan Kaitannya. Dengan Upaya Peningkatan Nilai Perusahaan. Jurnal Ekonomi dan Bisnis, 18(1), 83-99.

Heaney, R., Naughton, T., Truong, T., Davidson, S., Fry, T., \& McKenzie, M. (2007). The link between performance and changes in the size and stability of a firm's officers and directors. Journal of Multinational Financial Management, 17(1), 16-29.

Hermiyetti, \& Malik, E. N. (2013). The Influence of Good Corporate Governance Mechanism on Earnings Management: Empirical Study in Indonesian Stock Exchange Listed Company for Periods of 2006-2010. Indonesian Capital Market Review, 5(1).

Hermuningsih. (2013). Pengaruh Profitabilitas, Growth Opportunity, Struktur Modal Terhadap Nilai Perusahaan Pada Perusahaan Publik di Indonesia. Buletin Ekonomi Moneter dan Perbankan.

Huang, W., Jiang, F., Liu, Z., \& Zhang, M. (2011). Agency cost, top executives' overconfidence, and investment-cash flow sensitivity—Evidence from listed companies in China. Pacific-Basin Finance Journal, 19(3), 261-277.

Humphrey-Jenner, M. L., \& Powell, R. G. (2011). Firm size, takeover profitability, and the effectiveness of the market for corporate control: Does the absence of anti-takeover provisions make a difference? Journal of Corporate Finance, 17(3), 418-437. doi: https://doi.org/10.1016/j.jcorpfin.2014.02.009

Irandoost, R., Hassanzadeh, R. B., \& Salteh, H. M. (2013). The Effect of Dividend Policy on Stock Price Volatility and Investment 
Decisions. European Online Journal of Natural and Social Sciences, 2(3), 51-59.

Jensen, M. C., \& Meckling, W. H. (1976). Theory of the firm: Managerial behavior, agency costs and ownership structure. Journal of Financial Economics, 3(4), 305-360.

John, S. F., \& Muthusamy, K. (2010). Leverage, growth and profitability as determinants of dividend payout ratio-evidence from Indian paper industry. Asian Journal of Business Management Studies, 1(1), 26-30.

Kang, T., Lobo, G. J., \& Wolfe, M. C. (2015). Accounting Conservatism and Firm Growth Financed by External Debt The Role of Debt Maturity. Journal of Accounting, Auditing \& Finance.

Kato, H. K., Loewenstein, U., \& Tsay, W. (2012). Dividend Policy, Cash Flow, and Investment in Japan. Pacific-Basin Finance Journal, 10 (4).

Madanoglu, M., Lee, K., \& Castrogiovanni, G. J. (2011). Franchising and firm financial performance among U.S. restaurants. Journal of Retailing, 87, 406-408.

Mai, M. U. (2010). Impact Of Dividend Policy On Company Value In Managerial Opportunistic Behavioral Conduct And Corporate Governance Structure Empirical Study on Manufacturing Companies Go Public In Indonesian Capital Market. Dissertation, Universitas Diponegoro, Semarang, Indonesia.

Mai, M. U. (2017). Mediation of CSR and Profitability on the Influences of GCG Mechanism to the Firm Value. Jurnal Keuangan dan Perbankan 21(2), 253-264

Modigliani, F., \& Miller, M. H. (1958). The Cost of Capital, Corporation Finance and The Theory of Investment. American Economic Review, 48(13), 261-297.

Murhadi, W. R. (2011). Determinan Struktur Modal: Studi di Asia Tenggara. Jurnal Manajemen dan Kewirausahaan, 13(2), 91-98.

Myers, S. C. (1984). Finance theory and financial strategy. Interfaces, 14(1), 126-137.

Nhung, N. T. P., Lien, N. P., \& Hang, D. T. T. (2017). Analyze the Determinants of Capital Structure for Vietnamese Real Estate Listed Companies. International Journal of Economics and Financial Issues, 7(4).

Nur, T. (2014). Searching for Determinants of Pay or Not to Pay Cash Dividend in Indonesia. Indonesian Capital Market Review, $6(1)$.

Nuswandari, C. (2013). Determinan Struktur Modal Dalam Perspektif Pecking Order Theory dan Agency Theory. Dinamika Akuntansi Keuangan dan Perbankan, 2(1).

Ovtcharova, G. (2003). Institutional Ownership and Long Term Stock Returns. Working Paper.

Pagalung, G. (2002). Effect of Combination of the advantages and limitations of the Company to the Investment Opportunity Set (IOS). Paper presented at the National Symposium Accounting 5, Semarang.

Panno, A. (2003). An Empirical Investigation on The Determinants of Capital Structure: the UK and Italian Experience. Applied Financial Economics, 13, 97-112.

Prasetyantoko, A. (2006). Financing Constraint and Firm Investment Following a Financial Crisis. Paper presented at the 23 ${ }^{\text {rd }}$ International Symposium on Banking and Monetary Economics.

Purnamawati, I. G. A., Yuniarta, G. A., \& Astria, P. R. (2017). Good Corporate Governance dan Pengaruhnya Terhadap Nilai Perusahaan Melalui Corporate Social Responsibility Disclosure. Jurnal Keuangan dan Perbankan 21(2), 276-286.

Qureshi, S. U., \& Sharif, S. (2012). Impact of TQM practices on firm's performance of Pakistan's manufacturing organizations. International Journal of Academic Research in Business and Social Sciences, 2(10).

Raz, K. R., \& Amir, M. (2014). A Review of Interaction of Financial Leverage and Investment Opportunities on Dividend Policy. Researcher 4.

Robiyanto, R. (2015). Month of the year effect pada beberapa pasar modal di Asia Tenggara dan pasar komoditas. Jurnal Ekonomi dan Bisnis, 18(2), 53-64. doi: 10.24914/jeb.v18i2.260

Robiyanto, R., \& Puryandani, S. (2015). The Javanese lunar calendar's effect on Indonesian stock returns. Gadjah Mada International Journal of Business, 17(2), 125-137. doi: 10.22146/gamaijb.6906

Robiyanto, R., Wahyudi, S., \& Pangestuti, I. R. D. (2017). The volatility-variability hypotheses testing and hedging effectiveness of precious metals for the Indonesian and Malaysian capital markets. Gadjah Mada International Journal of Business, 19(2), 167-192. doi: 10.22146/gamaijb.26260

Sahabuddin, Z. A. (2017). Asset Structure Impact on Capital Structure of Capital Market-Listed Firms in Indonesia and Malaysia. Jurnal Keuangan dan Perbankan 21(3).

Siahaan, F. O. (2013). The Effect of Good Corporate Governance Mechanism, Leverage, and Firm Size on Firm Value. GSTF Journal on Business Review, 2(4).

Skinner, D. J., \& Soltes, E. (2009). What Do Dividends Tell Us About Earnings Quality. Review of Accounting Studies.

Subramaniam, R. K., \& Shaiban, M. S. (2011). Investment opportunity set and dividend policy in Malaysia: Some evidence on the role of ethnicity and family control. Paper presented at the International Conference on Economics, Business and Management. 
Suprianto, E., \& Setiawan, D. (2017). Manajemen Laba di Indonesia: Studi Sebuah Bibliograpi. Jurnal Keuangan dan Perbankan, 21(2), 287-301.

Suteja, J., \& Mayasari, A. N. (2017). Is Investment Policy Value-Enhancing through CSR Disclosure? Jurnal Keuangan dan Perbankan 21(4).

Symeou, P. C. (2011). The firm size - performance relationship: an empirical examination of the role of the firm's growth potential. Working Paper.

Taungke, N., \& Supramono, S. (2015). Ex-dividend Date dan Perubahan Harga Saham. Jurnal Keuangan dan Perbankan, 19 (3).

Tyastari, T. T. D., Rosidi, R., \& Saraswati, E. (2017). Dividend Policy and Corporate Value (A Meta-Analysis). Jurnal Keuangan dan Perbankan 21(3).

Ullah, H., Fida, A., \& Khan, S. (2012). The Impact of Ownership Structure on Dividend Policy Evidence from Emerging Markets. KSE-100 Index Pakistan. International Journal of Business and Social Science, 3(9), 298-307.

Wahyudi, S. (Cartographer). (2005). Shifting Development Strategy Jakarta Stock Exchange (JSX): Growth Liberal Towards Fair Competition.

Wijaya, R. (2017). Kinerja Keuangan dan Ukuran Perusahaan terhadap Harga Saham dengan Kebijakan Dividen sebagai Variabel Intervening. Jurnal Keuangan dan Perbankan, 21(3).

Zheng, Y. (2017). Three Essays on Capital Structure and Product Market Interactions. Doctoral Dissertation. Retrieved from website: http://scholarcommons.sc.edu/etd/4117 